\title{
SOSIALISASI PROTOKOL KESEHATAN SEBAGAI UPAYA PENCEGAHAN COVID- 19 KEPADA MASYARAKAT NELAYAN DI PESISIR KUALA BUBON KABUPATEN ACEH BARAT
}

\section{THE SOCIALIZATION OF HEALTH PROTOCOL AS THE EFFORT OF COVID-19 PREVENTIVE FOR FISHERMEN COASTAL'S COMMUNITY AT KUALA BUBON, WEST ACEH}

\author{
${ }^{1}$ Mohamad Gazali, ${ }^{2}$ Zuriat, ${ }^{2}$ Amarullah, ${ }^{3} \mathrm{M}$. Ali Sarong, ${ }^{1}$ Endah Anisa Rahma, ${ }^{1}$ Mai Suriani, ${ }^{4}$ Rina \\ Syafitri, ${ }^{5}$ Sulaiman Ali \\ ${ }^{1}$ Prodi IImu Kelautan, Fakultas Perikanan dan Ilmu Kelautan Universitas Teuku Umar \\ ${ }^{2}$ Prodi Perikanan, Fakultas Perikanan dan Ilmu Kelautan Universitas Teuku Umar \\ ${ }^{3}$ Prodi Pendidikan Biologi, FKIP Universitas Syiah Kuala \\ ${ }^{4}$ Prodi Agribisnis, Fakultas Pertanian Universitas Teuku Umar \\ ${ }^{5}$ Prodi Teknik Mesin, Fakultas Teknik Universitas Teuku Umar \\ *Korespondensi Penulis : mohamadgazali@utu.ac.id
}

\begin{abstract}
ABSTRAK
Virus Corona (COVID-19) merupakan sejenis virus yang mematikan dengan proses penyebaran yang cepat. Virus ini menginfeksi saluran pernafasan manusia. Mencegah penyebaran COVID-19, segala aktivitas harus mengikuti protokol kesehatan yang sudah diterbitkan oleh Kemenkes RI seperti social distancing, memakai masker dan mencuci tangan. Tujuan kegiatan ini adalah untuk memberikan pemahaman kepada masyarakat nelayan Kuala Bubon terkait protokol kesehatan sebagai upaya pencegahan COVID-19 serta menyerahkan bantuan touchless hand washer untuk memudahkan masyarakat mengikuti protokol kesehatan. Kegiatan pengabdian ini dilakukan dengan metode ceramah/pendampingan. Adapun luaran dari kegiatan pengabdian ini yaitu adanya peningkatan kesadaran masyarakat untuk selalu mengikuti protokol kesehatan dalam setiap aktivitasnya. Kegiatan pengabdian kepada masyarakat ini mendapat sambutan positif dari masyarakat setempat. Hal ini dapat dilihat dari antusias masyarakat dalam mengikuti kegiatan ini.
\end{abstract}

Kata kunci : Protokol Kesehatan, Covid-19, Nelayan

\begin{abstract}
Corona virus (COVID-19) is a type of deadly virus with a fast spreading process. This virus infects the human respiratory tract. To prevent the spread of COVID-19, all activities must follow the health protocols published by the Indonesian Ministry of Health, such as social distancing, wearing masks and washing hands. The aim of this study is to provide understanding to the Kuala Bubon fishing community regarding health protocols as an effort to prevent COVID-19 and to provide touchless hand washer assistance to make it easier for people to do health protocols. This study which is a part of community service activity was conducted by using the lecture/mentoring method. The output of the activity is an increase of public awareness to always follow health protocols to every activity. The activity received a positive response from the local community. This can be seen from the enthusiasm of the community in participating in this community service activity.
\end{abstract}

Keywords : Health protocols, Covid-19, fishermen 


\section{PENDAHULUAN}

\section{Latar Belakang}

Pandemic COVID-19 ini sudah mulai pada bulan Januari 2020 yang berasal dari Kota Wuhan, Cina. Virus yang mematikan ini ternyata dapat menyebar dengan begitu cepat ke seluruh Dunia khususnya Indonesia sehingga WHO menetapkan pandemic darurat dunia. Organisasi internasional bidang kesehatan World Health Organization (WHO) menyatakan bahwa COVID-19 memiliki kemampuan menginfeksi saluran pernapasan pada manusia. COVID-19 dapat memberikan gejala-gejala mulai dari flu yang ringan sampai kepada yang sangat serius setara atau bahkan lebih parah dari MERS-CoV dan SARS-CoV (Kirigia dan Muthuri, 2020). COVID-19 telah menyebar begitu cepat ke seluruh penjuru dunia dan berubah menjadi pandemi yang menakutkan bagi masyarakat dunia. Hingga saat ini ditemukan 93 negara yang telah terjangkit COVID-19. Pandemi COVID-19 yang telah menyebar pada akhirnya membawa risiko yang sangat buruk bagi perekonomian dunia termasuk Indonesia khususnya dari sisi pariwisata, perdagangan serta investasi di sektor perikanan dan kelautan. Pandemic COVID-19 memberikan dampak negatif bagi masyarakat pesisir khususnya masyarakat nelayan (Kurnia, 2020). Pandemik COVID-19 telah berdampak pada berbagai aspek kehidupan meliputi aspek ekonomi, sosial dan masyarakat. Menurut Pemerintah Indonesia melakukan langkah-langkah konkrit untuk memutuskan mata rantai infeksi COVID-19 dengan melakukan sosialisasi gerakan social distancing, memakai masker dan mencuci tangan. Protocol kesehatan wajib diterapkan oleh seluruh pelaku usaha perikanan dan kelautan selama pandemic COVID-19 (Buana, 2020). Segala aktivitas perikanan dan kelautan harus mengikuti protocol kesehatan untuk mencegah penyebaran COVID-19. Dalam penanggulangan protocol kesehatan terdapat tiga fase yaitu fase pencegahan, fase deteksi dan fase respon (Suni, 2020).

Masyarakat nelayan perlu memahami protocol kesehatan COVID-19 yang sudah diterbitkan oleh Kemenkes RI. Hal ini berkaitan dengan aspek sosial masyarakat pesisir sangat rentan dengan penularan COVID-19 karena memiliki interaksi berantai dengan masyarakat yang luas. Penularan COVID-19 kepada masyarakat nelayan tentunya berdampak besar terhadap produksi perikanan, pemasaran hasil perikanan hingga pada level konsumen dan industri yang berkimpung di sektor perikanan dan bahkan secara global akan mempengaruhi pada pola perikanan nasional.

Beberapa pengaruh pandemic COVID-19 pada sektor perikanan dan kelautan yang sudah dipublikasi oleh media massa (Antara, 2020) yang menerangkan bahwa dampak COVID-19 berpengaruh pada penurunan ekspor komodits perikanan sehingga berimbas pada penurunan pendapatan nelayan serta terputusnya rantai pasok hasil perikanan (Grahadyarini, 2020).

Hal yang sama juga berimbas pada masyarakat nelayan yang ada di Pesisir Kuala Bubon Kabupaten Aceh Barat Propinsi Aceh. Wilayah pesisir Kuala Bubon memiliki Pelabuhan Pelelangan Ikan (PPI) yang merupakan lokasi distribusi hasil tangkapan hingga ke tangan konsumen. Hal ini menarik perhatian peneliti untuk melakukan kegiatan pengabdian kepada masyarakat terkait dengan protocol kesehatan bagi masyarakat nelayan. 


\section{Permasalahan}

Masyarakat Aceh Barat sangat bergantung pada komoditas perikanan sebagai sumber pangan utama. Disisi lain, wilayah Aceh khususnya Aceh Barat memiliki karakteristik pesisir dan laut yang berhadapan langsung dengan Samudera Hindia memiliki potensi sumberdaya perikanan yang tinggi untuk memenuhi kebutuhan protein. Namun, pada masa pandemic COVID-19, dimana mobilisasi masyarakat dibatasi karena adanya kekhawatiran penularan COVID-19. Hal ini berdampak pada sektor perikanan yang ada di Aceh Barat khususnya di wilayah Kuala Bubon. Selain itu, pemahaman terkait protocol kesehatan sebagai upaya pencegahan COVID-19 belum dipahami dengan baik oleh seluruh masyarakat nelayan sehingga sangat rentan dengan penularan virus corona. Hal ini melatarbelakangi peneliti untuk melakukan kegiatan PkM sekaligus memberikan bantuan Touchless hand washer yang ditempatkan di PPI Kuala Bubon Aceh Barat.

\section{Tujuan Pelaksanaan}

Tujuan pelaksanaan kegiatan pengabdian kepada masyarakat ini adalah Memberikan pemahaman kepada masyarakat nelayan Kuala Bubon terkait protocol Kesehatan sebagai upaya penanggulangan COVID-19 di wilayah pesisir Kuala Bubon.

\section{METODE PELAKSANAAN}

\section{Tempat dan Waktu}

Pelaksanaan kegiatan ini telah dilaksanakan pada tanggal 18 Mei 2020 di PPI Kuala Bubon Gampong Kuala Bubon Kecamatan Samatiga Kabupaten Aceh Barat Propinsi Aceh.

\section{Teknik Pelaksanaan}

Teknik yang digunakan dalam menyelesaikan pemasalahan yaitu langkah awal dengan melakukan sosialisasi protocol kesehatan sebagai upaya penanggulangan pandemic COVID-19 bagi masyarakat nelayan Kuala Bubon. Adapun tahapan pekerjaan dalam menyelesaikan permasalahan dan sekaligus pencapaian tujuan program adalah sebagai berikut :

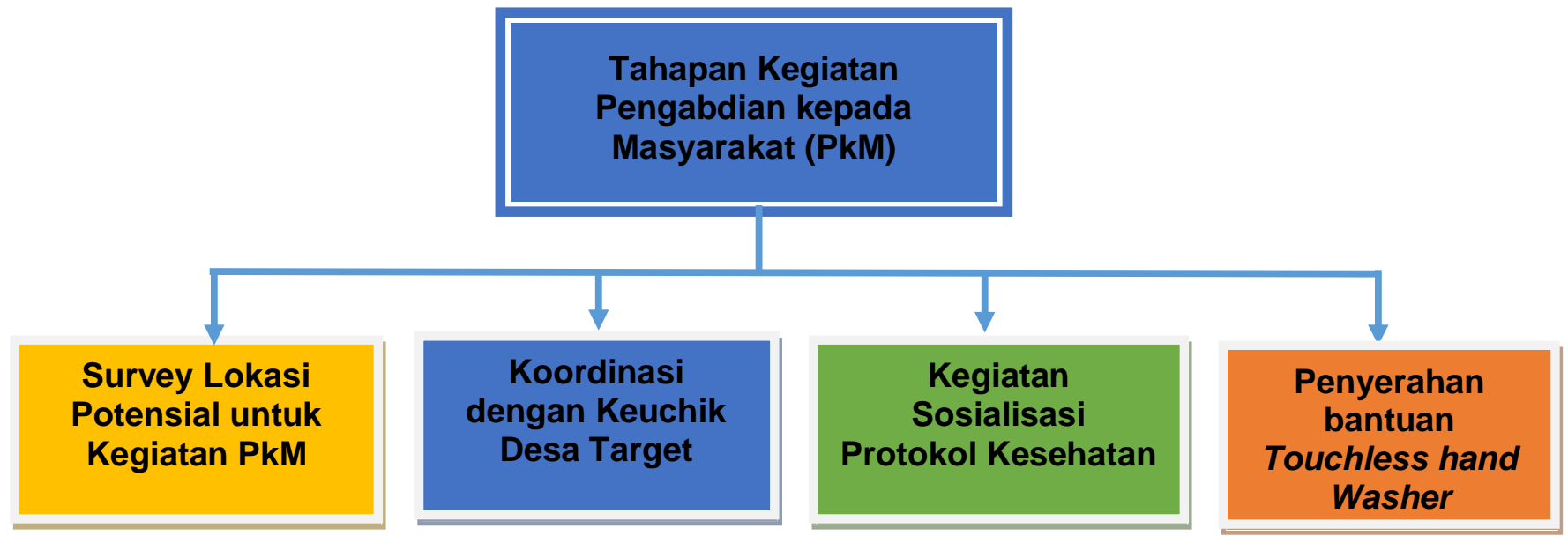

Gambar 1. Tahapan Pelaksanaan 


\section{HASIL DAN PEMBAHASAN}

Sosialisasi Protocol Kesehatan kepada Masyarakat Nelayan sangat penting dilakukan sebagai upaya pencegahan penularan COVID-19. Kami memberikan pemahaman terkait bahaya virus Corona yang berasal dari Wuhan Cina yang dapat tertular melaui droplet sehingga orang yang terpapar melalui udara akan mengalami gejala-gejala COVID-19 seperti mengalami demam, batuk-batuk dan sesak pada pernapasan hingga mengalami kematian. Kami dari Prodi Ilmu Kelautan Fakultas Perikanan dan Ilmu Kelautan Universitas Teuku Umar melakukan bekerjasama dengan aparatur Gampong Kuala Bubon melakukan Sosialisasi Protokol kesehatan. Kegiatan pengabdian kepada masyarakat ini mendapat sambutan positif dari Ketua Jurusan IImu Kelautan. Harapan beliau, semoga Pandemi COVID-19 segera berakhir sehingga aktivitas nelayan kembali normal (Gambar 2).

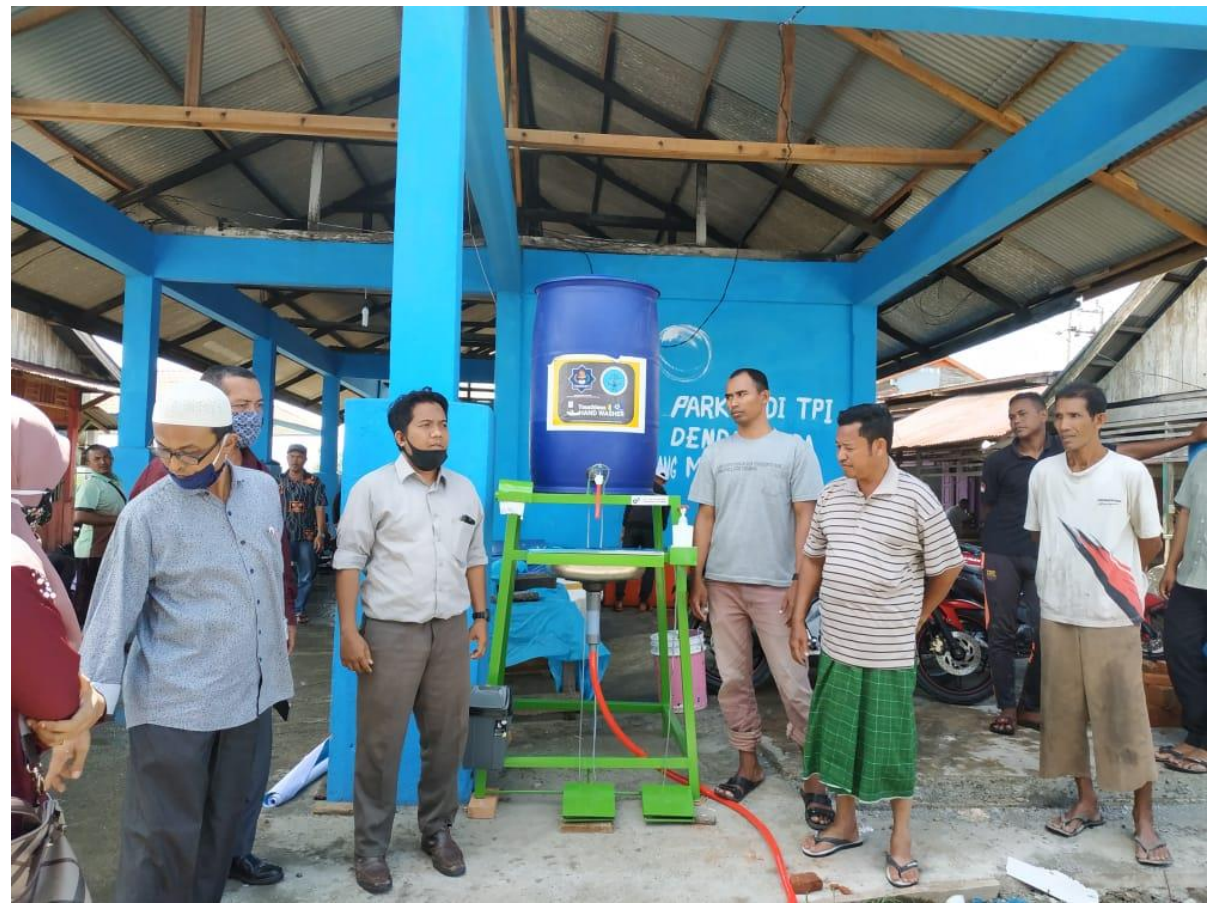

Gambar 2. Ketua Jurusan IImu Kelautan memberikan sambutan dalam kegiatan PkM di Gampong Kuala Bubon.

Sesuai arahan dari Kemenkes bahwa protocol kesehatan yang dihimbau kepada seluruh masyarakat antara lain sebagai berikut :

1. Menggunakan masker kapan saja dan dimana saja

2. Tidak terlalu panic dan selalu waspada

3. Menjaga kebersihan tangan dan hindari menyentuh bagian wajah sebelum mencuci tangan

4. Selalu menjaga jarak dalam melakukan aktivitas

5. Menghindari kerumunan/keramaian baik ditempat tertutup maupun tempat terbuka.

6. Mencipta ventilasi rumah yang baik dengan membuka jendela rumah agar sirkulasi udara berjalan baik.

Penjelasan mengenai protocol kesehatan disampaikan oleh ibu endah Anisa Rahma, M.Pd dan Pak Amarullah, M.Pi. Tim PkM FPIK Universitas Teuku Umar 
menjelaskan bahaya virus corona dan pentingnnya kita menerapkan protocol kesehatan bagi masyarakat nelayan Pesisir Kuala Bubon (Gambar 3).

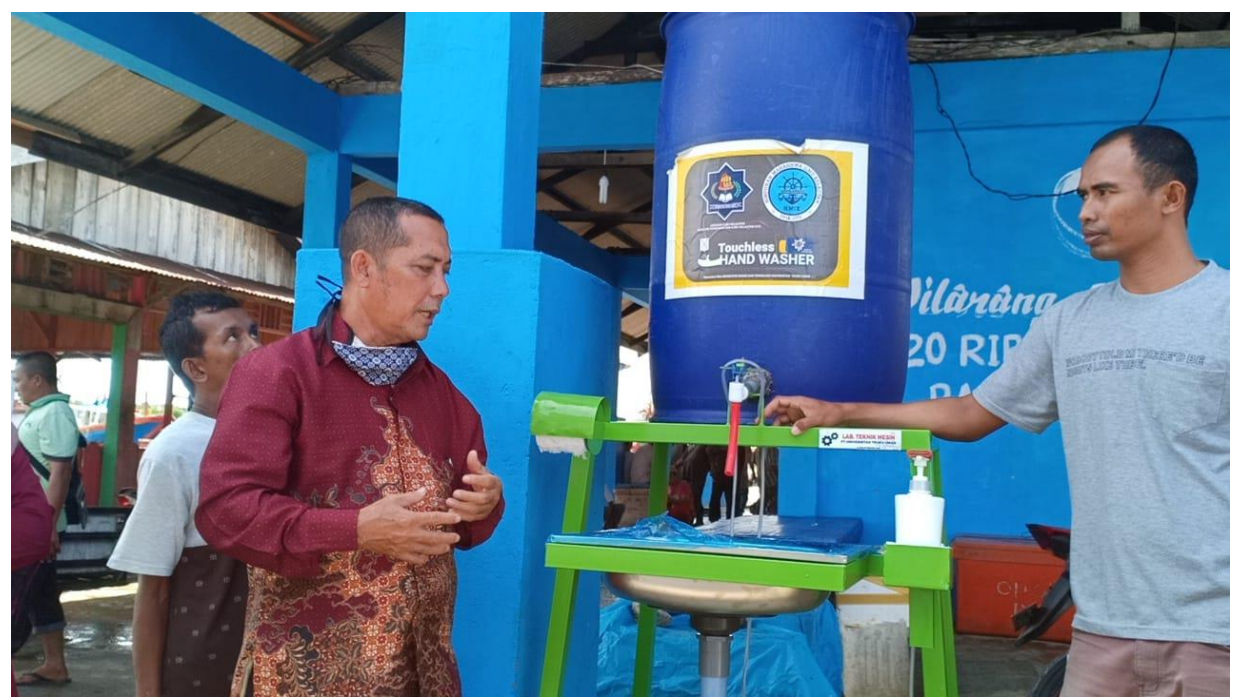

Gambar 3. Tim PkM melakukan sosialisasi protocol kesehatan kepada masyarakat Nelayan Kuala Bubon.

Selain itu, Tim PkM juga menjelaskan dampak pandemic COVID-19 terhadap sektor perikanan yang berimbas pada pendapatan nelayan pada umumnya. Oleh karena itu, pemerintah berusaha memberikan bantuan ekonomi bagi masyarakat yang terkena dampak dari pandemic COVID-19. Selain itu, berusaha mencari alternatif mata pencaharian sampingan yang membantu kebutuhan sehari-hari. Materi sosialisasi terkait dampak pandemic COVID-19 disampaikan oleh Bapak Ir. H. Zuriat, M.Si. Beliau menyampaikan bahwa masa pandemic COVID-19 mempengaruhi supply chain komoditas perikanan menjadi tidak efektif dan efisien (Gambar 4).

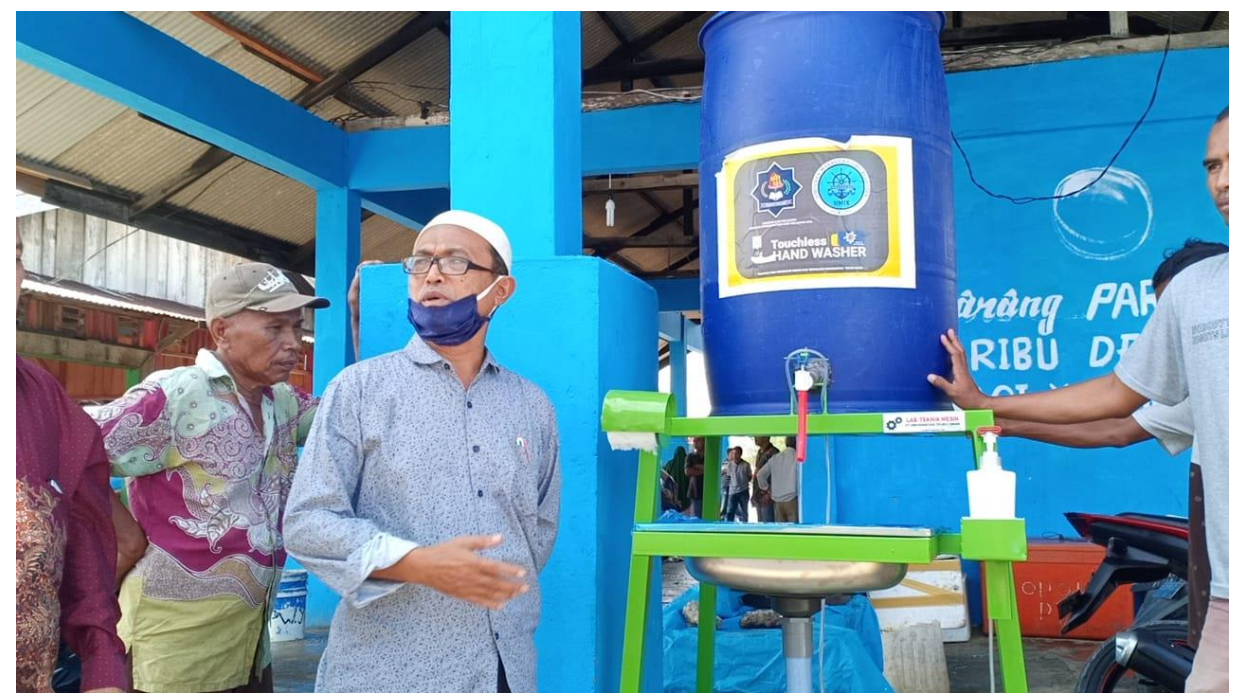

Gambar 4.Tim PkM FPIK UTU menjelaskan dampak pandemic COVID-19 bagi masyarakat nelayan 


\section{Penyerahan Bantuan Touchless Hand Washer}

Setelah melakukan sosialisasi, tim PkM FPIK-UTU menyerahkan bantuan Touchless Hand Washer yang diserahkan langsung oleh Ketua Jurusan IImu Kelautan FPIK Universitas Teuku Umar kepada Keuchik Kuala Bubon yang bertempat di PPI Kuala Bubon. Tujuan alat Touchless Hand Washer ini sebagai upaya pencegahan COVID-19. Dengan alat tersebut, masyarakat nelayan dengan mudah mengikuti protocol kesehatan seperti mencuci tangan setiap selesai menyelesaikan aktivitas perikanan di PPI Kuala Bubon (Gambar 5).

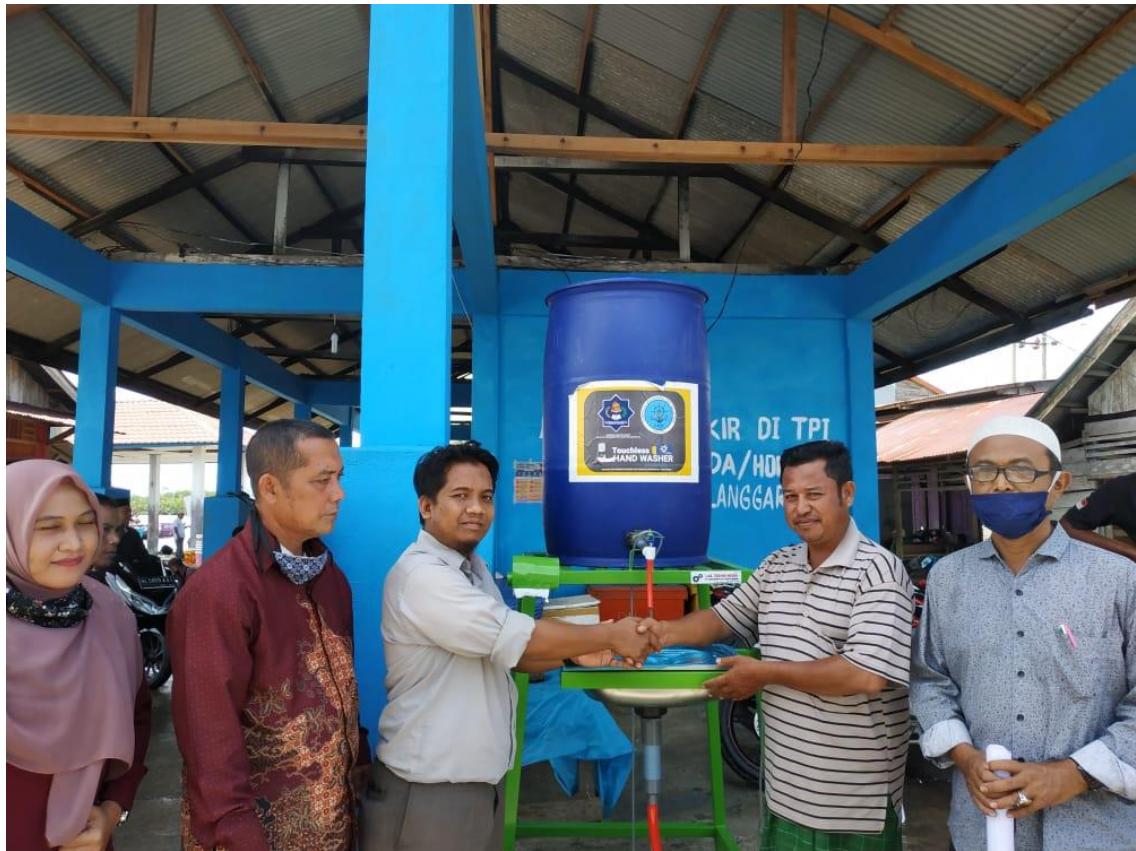

Gambar 5. Tim PkM yang diketuai oleh Ketua Jurusan menyerahkan bantuan alat Touchless Hand Washer

Tim PkM FPIK Universitas Teuku Umar berharap bantuan alat Touchless Hand Washer dapat dimanfaatkan oleh masyarakat Nelayan Kuala Bubon dengan baik sebagai upaya kepedulian kepada masyarakat dan perwujudan Tridharma Perguruan Tinggi.

\section{SIMPULAN DAN SARAN Simpulan}

Berdasarkan hasil dan pembahasan dapat ditarik kesimpulan bahwa masyarakat nelayan Kuala Bubon belum memahami secara keseluruhan tentang protocol kesehatan yang ditetapkan oleh Pemerintah Indonesia sebagai Upaya pencegahan penularan COVID-19. Oleh karena itu, tim PkM FPIK Universitas Teuku Umar sebagai bentuk pengabdian kepada masyarakat melaksanakan sosialisasi protocol kesehatan kepada masyarakat Gampong Kuala Bubon Kecamatan Samatiga Kabupaten Aceh Barat Propinsi Aceh.

\section{Saran}

Perlu adanya peran tokoh masyarakat dalam menginformasikan protocol kesehatan kepada masyarakat setempat. 


\section{UCAPAN TERIMA KASIH}

1. Dalam mensukseskan kegiatan pengabdian kepada masyarakat ini tidak terlepas dari kerjasama yang baik dengan Himpunan Mahasiswa IImu Kelautan (HMIK) atas kerjasama dan kekompakan dalam kegiatan sosialisasi sosialisasi kami ucapkan terima kasih yang setinggi-tingginya.

2. Ucapan terima kasih kepada Keuchik Gampong Kuala Bubon yang memberikan izin melakukan kegiatan sosialisasi protocol kesehatan sehingga menambah khazanah ilmu pengetahuan bagi masyarakat pesisir.

3. Masyarakat pesisir Kuala Bubon dan mahasiswa yang antusias ikut serta dalam kegiatan pengabdian kepada masyarakat.

\section{DAFTAR PUSTAKA}

Antara, A. (2020, April 2). Dampak Corona, Nasib Nelayan Perlu Dipikirkan. Bisnis.Com.

Retrieved from https://ekonomi.bisnis.com/read/20200402/99/1221362/dampakcorona-nasibnelayan-perlu-dipikirkan.

Buana, D. R. (2020). Analisis Perilaku Masyarakat Indonesia dalam Menghadapi Pandemi Virus Corona (Covid-19) dan Kiat Menjaga Kesejahteraan Jiwa. ALAM: Jurnal Sosial Dan Budaya Syar-I, 7(3). https://doi.org/10.15408/sjsbs.v7i3.15082

Grahadyarini, L. (2020, April 20). Pembudidaya dan Nelayan Terpuruk. Kompas. Retrieved from https://kompas.id/baca/ekonomi/2020/04/20/pembudidaya-dannelayan-terpuruk/

Kemenkes RI. (2020). Pedoman Pencegahan dan Pengendalian Coronavirus Disease (COVID19). Germas, 0-115.

Kurnia, L. (2020). Dampak COVID-19 Terhadap Sektor Pariwisata. Journal Contribution. https://doi.org/https://doi.org/10.6084/m9.figshare.11996295.v1.

Kirigia, J. M., dan Muthuri, R. N. D. K. (2020). The Fiscal Value of Human Lives Lost From Coronavirus Disease (COVID-19) in China. BMC Research Notes, 13(1), 1-5. https://doi.org/10.1186/s13104-020-05044-y

Suni, N. S. P. (2020). Kesiapsiagaan Indonesia Menghadapi Potensi Penyebaran Corona. Pusat Penelitian Badan Keahlian DPR RI, XII(3/I). 